\title{
The Phenomenon of Social Enterprises: Are We Keeping Watch on This Cultural Practice?
}

\author{
Claudinei Pereira Gonçalves ${ }^{1}$ (D) Kester Carrara $^{2}$ • \\ Richardson Moro Schmittel ${ }^{3}$
}

(C) International Society for Third-Sector Research and The Johns Hopkins University 2015

\begin{abstract}
Social enterprises have reached world levels as an alternative to combat negative effects of the economy such as unemployment, poor distribution of income, and poverty, thus stimulating social entrepreneurship with local actions directed especially to excluded communities. This article corresponds to a study that uses the bibliometric method to analyze the world scientific literature on social enterprises in order to research on the possible existence of investigation projects that may have approached the cultural dimension of said phenomenon. Studies in this field may contribute to the establishment of social enterprises as a cultural practice, for the promotion of a more equitable social and economic development. The analysis of the scientific publications inherent to the topic, suggests, among other results, that the academic production is diverse, but there is still a lack of initiatives in order to explore new perspectives concerning the phenomenon. On the other hand, similarities in the motivation of the studies allow outlining 10 categories that evidence the most interest in the research on social enterprises.
\end{abstract}

Résumé Les entreprises sociales ont obtenu le statut d'alternative mondiale pour réduire les effets négatifs de l'économie dans la vie contemporaine, tels que la dégradation de l'environnement, le chômage, l'inégalité des revenus et la pauvreté,

Claudinei Pereira Gonçalves

claudinei.pg@gmail.com

Kester Carrara

kester.carrara@uol.com.br

Richardson Moro Schmittel

richardson.moro@gmail.com

1 Instituto Federal de Educação, Ciência e Tecnologia do Espírito Santo and Universidade Federal do Espírito Santo, Vitória, Brazil

2 Universidade Estadual Paulista Júlio de Mesquita Filho, Bauru, Brazil

3 Faculdades Integradas de Aracruz, Aracruz, Brazil 
stimulant ainsi l'entrepreneuriat social avec des actions locales notamment pour les communautés exclues. Cet article utilise la méthode bibliométrique pour analyser la production scientifique mondiale sur les entreprises sociales. L'analyse des publications scientifiques en rapport avec notre thème indique, parmi d'autres résultats, que la production universitaire est faible mais qu'elle se développe rapidement et est émergente dans le monde entier. Parmi les différents sujets examinés, le problème du développement de la gestion d'entreprise est l'un des plus importants. Néanmoins, nous avons encore besoin d'initiatives pour explorer de nouvelles perspectives du phénomène qui tiennent compte, par exemple, du progrès mondial des entreprises sociales comme pratique culturelle favorisant un développement socioéconomique plus équitable.

Zusammenfassung Sozialunternehmen haben inzwischen den Status einer globalen Alternative zur Reduzierung der negativen wirtschaftlichen Auswirkungen im modernen Leben, wie ökologische Degeneration, Arbeitslosigkeit, Einkommensungleichheit und Armut, wobei das soziale Unternehmertum durch lokale Maßnahmen insbesondere für ausgegrenzte Gemeinschaften stimuliert wird. In diesem Artikel wird die bibliometrische Methode angewandt, um die globale wissenschaftliche Produktion zu sozialen Unternehmen zu untersuchen. Die Analyse wissenschaftlicher Veröffentlichungen zu unserem Thema weist unter anderem darauf hin, dass die akademische Produktion zwar klein ist, jedoch derzeit weltweit zunimmt. Einer der wichtigsten Diskussionspunkte ist das Problem der Entwicklung des Unternehmensmanagements. Trotzdem benötigen wir noch immer Initiativen zur Erforschung neuer Perspektiven zu dem Phänomen, die beispielsweise den globalen Fortschritt der sozialen Unternehmen als eine kulturelle Praktik berücksichtigen, die eine gerechtere sozio-öknonomische Entwicklung fördert.

Resumen Los empresas sociales han logrado el estatus de una alternativa global para reducir los efectos negativos de la economía en la vida contemporánea, tales como la degradación medioambiental, el desempleo, la desigualdad de ingresos y la pobreza, estimulando el emprendimiento social con acciones locales especialmente para las comunidades excluidas. El presente artículo utiliza el método bibliométrico para analizar la producción científica global sobre las empresas sociales. El análisis de publicaciones científicas relacionadas con nuestro tema sugiere, entre otros resultados, que la producción académica es pequeña, pero está creciendo y emergiendo en todo el mundo. Entre los diversos temas tratados, la preocupación por el desarrollo de la gestión empresarial es uno de los más importantes. Sin embargo, seguimos necesitando iniciativas para explorar nuevas perspectivas del fenómeno, que consideren, por ejemplo, el progreso global de las empresas sociales como una práctica cultural que fomenta un desarrollo socioeconómico más igualitario.

Keywords Social business - Social enterprise - Inclusive business - Cultural practice $\cdot$ Behavior analysis 
In the last 30 years, the dissemination of an innovative way of aligning the capitalist mechanical with socio-environmental issues has generated a global mobilization around a specific type of organization, which represents a social phenomenon that has been attracting the attention of researchers worldwide. Community enterprise, inclusive business, hybrid company, social business are some instances of the terminology attributed to this peculiar type of venture which is called in this study by a simple but comprehensive term: social enterprise. (Comini et al. 2012; Nwankwo et al. 2007).

The importance of social enterprises has been recognized twice by the Nobel committee (Haugh, 2012). First time in 2006 when Muhammad Yunus won the Nobel Peace Prize for his efforts to reduce poverty in Bangladesh, stimulating small businesses through microloans offered by the institution he founded, Grameen Bank (Yunus and Jolis 2007). The second was in 2009, when for the first time the prize in Economic Sciences was given to a woman, Elinor Ostrom, for her work about small communities which, instead of competing with each other for the same resources, learned to cooperate to survive, something that refute the idea popularized by the Tragedy of the Commons (Hardin 1968), according to which the human being is doomed to face conflict due to the scarcity of resources. Ostrom's research showed that in many cases, societies are able to thrive with the creation of alternatives to resolve conflicts of interest, respecting the others and ensuring environmental sustainability, without depending on governments or corporations (Ostrom 1990; Ostrom et al. 1999).

In addition to their social importance, the economic impact of social enterprises has attracted capital from all over the world, and generated a promising area with great potential of participation in the economy. Through interviews with 125 institutional investors at the end of 2013, the American bank JP Morgan and the Global Impact Investing Network estimated investments of 12.7 billion dollars in 2014 in this sector, $19 \%$ more than was invested in 2013 (Saltuk et al. 2014). In 2010, another study conducted with the support of the Rockefeller Foundation and released during the Rio +20 Corporate Sustainability Forum already announced a financial support of US\$ 400 billion to US\$ 1 trillion until 2020 (O’Donohoe et al. 2010). Considered a pioneer, UK maintains a governmental structure exclusively dedicated to the subject and impresses with its data. There are about 70.000 social enterprises that employ approximately one million people, and contribute to an investment of $£ 24$ billion to the British economy (U.K. Cabinet Office 2013).

To foment a more sustainable, just, and inclusive development, a whole ecosystem involving different actors, such as incubators, accelerators, investors, media, governments and educational institutions, has been structured to create an adequate environment for social enterprises have access to networks, financial investments, and technical support. Nonetheless, this scenario did not appear suddenly. In fact, it represents a set of cultural practices that evolved based on the emersion of Industrial Capitalism and on its consequences in the life of the worker.

Despite it being a term with broad meanings, culture can be understood, from behaviorist perspective, as a social phenomenon formed by a group of cultural practices within a determined society. Said cultural practices are behaviors that are similar among themselves and are learnt and disseminated by successive individuals 
throughout generations (Sampaio and Andery 2010). Since cultural practices correspond to interlocking behavior between individuals within a group, Skinner (1971) states that it is possible to describe a culture by means of the listing if its practices, be these of ethical, religious, economic, or racial origin, among others. With respect to the economic origin, both the capitalist and the socialist cultures are characterized by dominant institutions and systems that were established by means of cultural practices kept throughout time. In this contest, the social enterprises can be regarded as a cultural practice that broke out and keeps in the midst of the capitalist culture.

Ever since the first cooperatives, which date as back as the eighteenth century, until present times, more than 250 years of adaptation to excluding economic practices imposed by the development of the capitalist culture, have gone by. The cooperatives arose in the middle of the poverty, unemployment, and depression of the economic activity, in response to the very bad working conditions and the low salaries that deeply affected the life of the worker (Santos 2005; Singer 2002). Their purpose was to guarantee the survival of the working community. In those first social enterprises, the worker stopped being a mere resource for the exploitation of the bourgeoisie and moved to be part of the owner class of the production environments. Said inclusion strengthened the replication process of the same behaviors that led to the creation of the primitive cooperatives encouraging new generations to maintain and expand said actions in the form of a cultural practice which flourished in Western Europe and spread throughout the world and is known today as social enterprise.

Skinner (1981) suggests that it is possible to foresee and control the actions of individuals, as well as plan the cultural practices of a society. The work of social scientists such as Harris (1979, 1980, and 2007) and Diamond (2001, 2005) points at the cause-effect relations present in the evolution of cultures throughout many years of spreading of certain behaviors among groups of individuals. Recently, the studies of Glenn (Glenn 1986, 1988, 1991, 2003, 2004; Glenn and Malott 2004; Malott and Glenn 2006) concerning metacontingencies provide a new unit of analysis in order to visualize, not only the description and the planning of interventions that alter the path of cultural evolution, but also the development and maintenance of new practices. Numerous are the potential benefits of the studies of social enterprises as a cultural practice that promotes a more sustainable, fair, and inclusive development. The modeling in terms of optimization of this social phenomenon can, for example, offer capitalist culture countries public policy proposals directed toward the creation and maintenance of social enterprises as an alternative for a more balanced social and economic development with respect to the more traditional approaches. On the other hand, even in face of the probable contributions of the study of cultural practice of the social enterprises, preliminary research have led to the adoption of the assumption that research on social enterprises as cultural practice is a field under explored. In order to verify said assumption, this study has the following objectives: (a) to carry out a bibliometric analysis covering a decade of the world scientific literature on social enterprises, and (b) to identify possible studies that approach, even if in an underlying manner, the cultural dimension of the social enterprises phenomenon. 
Some bibliometric studies already address the social enterprise matter in a parallel manner or a superficial one when they analyzed the scientific literature on social entrepreneurship (Desa, 2007; Granados et al. 2011; Hill et al. 2010; Hoogendoorn et al. 2010; Short et al. 2009). However, since none of them was dedicated exclusively to the phenomenon of social enterprises, few were the specific contributions made to this field. Desa (2007) makes proposals on what the future holds for the social enterprises. Granados et al. (2011) present an epistemological orientation that justifies the study of the social enterprises as a discipline. Short et al. (2009) discuss the importance of having performance measurements based on profitable and non-profitable benefits. No direct contributions were found in the other studies, a fact that does not imply that there were no other more in-depth ones with respect to social entrepreneurship as a whole. Table 1 summarizes the characteristics of each bibliometric study and highlights the main contributions of this article with respect to the other publications.

Definitions of social enterprise may be found in different parts of the world. Their meaning varies in what respects to the forms of organization involved, but both the concepts issued by academic institutions or government institutions and those arising from the market, converge in the search of the state of well-being based on the commercialization of goods and services.

In the United States, both in academic and professional environment, the concept embraces three types of organizations: profit-driven companies that promote social benefits through philanthropic actions or in the performance of their corporate social responsibility; hybrid companies, which maintain both financial and social purposes; and nonprofit organizations involved in commercial activities to support their social purposes. This is type of most social enterprises in the USA and has the largest representation in the use of the concept in the country (Kerlin 2006).

In Latin America, Social Enterprise Knowledge Network (SEKN) defines social enterprises as organizations that generate social change by means of market activities. This covers non-governmental organizations as well as traditional organizations involved in well-being activities of the public sector (Comini et al. 2012).

In Europe, a social enterprise is defined by the Organization for Economic Cooperation and Development (OECD) as

Any private activity conducted in the public interest, organized with entrepreneurial strategy, but whose main purpose is not the maximization of profit but the attainment of certain economic and social goals, and which has the capacity for bringing innovative solutions to the problems of social exclusion and unemployment (Kerlin 2006, p. 251).

For the European Research Network (EMES) social enterprises "are not-forprofit private organizations providing goods or services directly related to their explicit aim to benefit the community" (Defourny and Nyssens 2008, p. 204).

In East Asia, the South Korean government defines social enterprise as "an organization which is engaged in business activities, such as producing and selling goods and services, while pursuing a social purpose of enhancing the quality of 


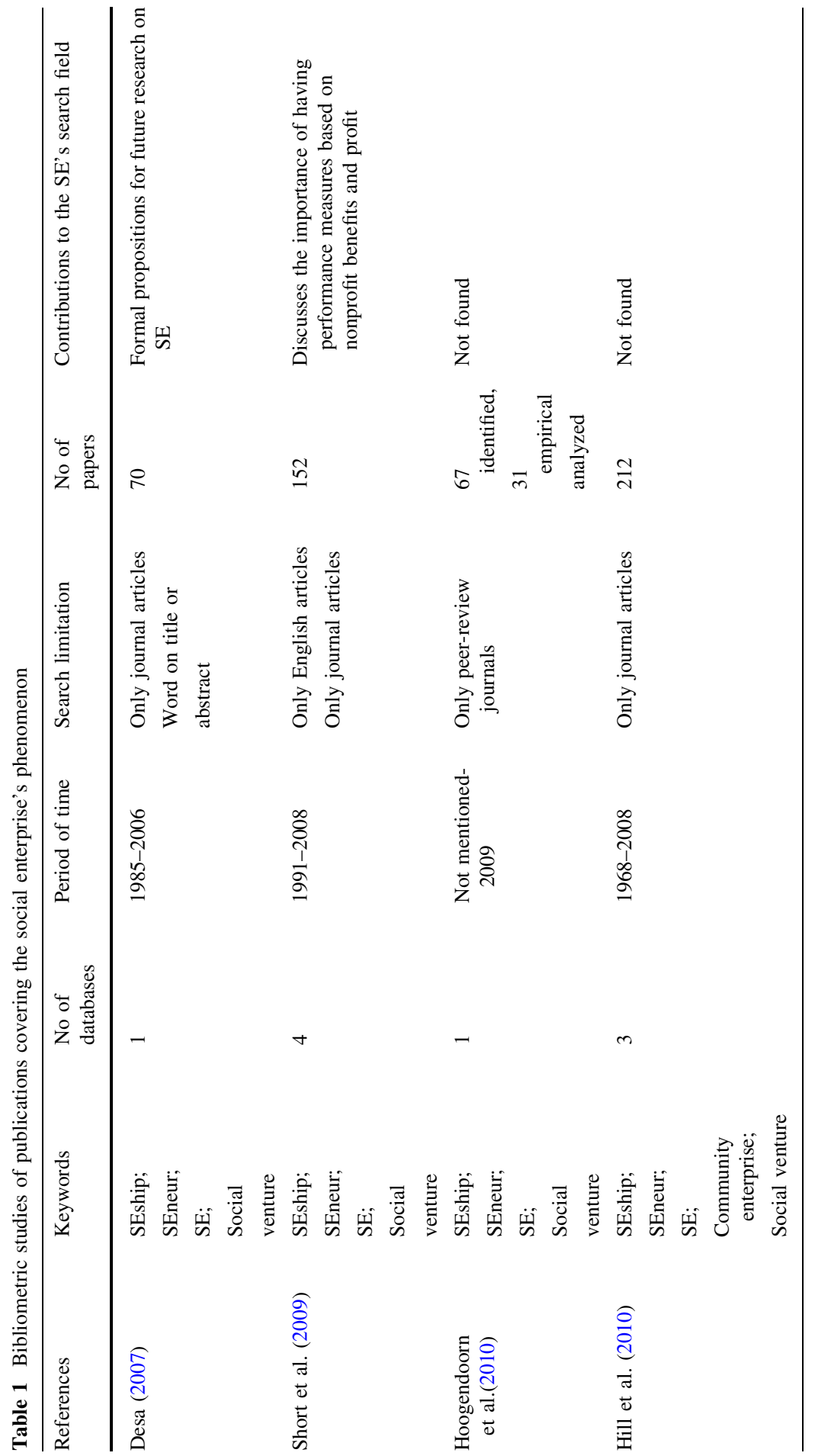




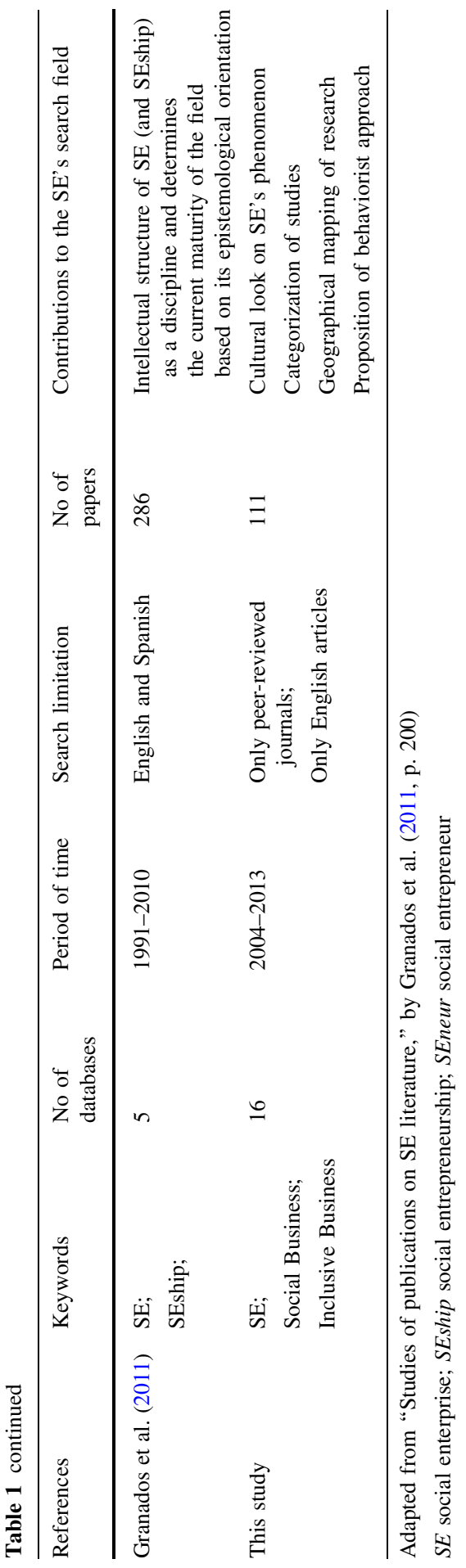


local residents' life by means of providing social services and creating jobs for the disadvantaged" (Bidet and Eum 2011, p. 77).

Despite the definitions converging in the search for the improvement of the state of well-being by means of business activities, the terminologies associated with social enterprises vary in accordance with the characteristics of every region. Comini et al. (2012) selected the terms social businesses, inclusive businesses, and social enterprises as the ones that best represent the different perspectives on the organizations that seek to achieve social objectives based on the use of market mechanisms.

Social business is the predominating term used in the United Stated and in Brazil to represent the logical market application for the resolution of social problems. In the US, the term initially referred to the business units incorporated to traditional companies and to hybrid companies that had social objectives associated to financial ones. Later it was also attributed to the commercial entrepreneurship of nonprofit organizations seeking financing alternatives for their operations (Comini et al. 2012; Dees 2007; Kerlin 2006). In Brazil, in 2003, the term came to be used starting from the strong presence of nonprofit organizations, accelerators, and investment funds specialized in the promotion of businesses with social impact, but it is still not associated with cooperatives, mutual funds, or any other legal form of Solidary Economy, a group of initiatives by the civil society directed towards the fight against social exclusion and unemployment (Kerlin 2010).

The term inclusive business arises more strongly in some emerging countries, especially in Latin America and Asia, and emphasizes on the use of market initiatives directed toward the reduction of poverty and the change in the social condition of marginalized individuals. Studies by the SEKN carried out between 2006 and 2009 point at the great capacity of implementation of inclusive businesses of the civil society and of the small and mid-size businesses. Its familiarity with the collaborative work emphasizes on the ability and openness that are necessary for the internationalization of innovations. This makes it possible for the low-income populations by them represented, to obtain good chances of being inserted as providers in the value chain of great corporations. In Asia, the term especially illustrates the pioneering of Peace Nobel Prize winner, Muhammad Yunus, in the fight against poverty. His models of microloans, which make the access to loans by small companies, are widely known, especially in countries such as India and Bangladesh. Yunus's work and his own figure have promoted the social enterprises and have inspired young people worldwide to pursue careers in this sector (Comini et al. 2012).

Social enterprise is the term most commonly used in Europe, and by influence in the countries of East Asia, Africa, and Oceania (Comini et al. 2012; Defourny and Kim 2011; Kerlin 2010). Despite it not being so popular in the United States, it was there that the term first arose in the 1970s in order to define activities which nonprofit entities began to carry out as a way of creating work opportunities for disadvantaged groups (Alter 2002). It was only in the 1990s that the term social enterprise broke out in Europe, it was widely promoted by an Italian newspaper called Impresa Sociale, becoming one of the pioneering initiatives that enabled the Italian parliament to create, a year later, the legal form called social cooperative 
(Defourny and Nyssens 2010). In 2004, the government of the United Kingdom attributed the term social enterprise to the entrepreneurships with social objectives, and the results of which were reinvested in the community or in the business itself, thus being able to operate in all market niches and solve a diversity of social and environmental matters. Between the publication of the Italian legislation in 1991 and the implementation by the British in 2004, other European countries introduced new ways of practicing commercial activities with social purposes, even if these were not legally called social enterprises (Defourny and Nyssens 2008). In France, Spain, Portugal, and Greece, new organizations were constituted in the manner of cooperative enterprises, while in Belgium, as in the United Kingdom and in Italy more comprehensive models of social enterprises were adopted. However, the establishment of denominations and structures by law did not prevent that the use of the term spread out throughout the rest of Europe and other continents, even in the form of traditional businesses and be adopted both in countries with regulations and in other regions (Defourny and Nyssens 2010).

Today it is possible to distinguish three categories in which the term social enterprise is used in Europe: (a) the companies whose main objective is the production of goods and services of social use or are led by a collective interest; (b) the organizations that promote local economic and social development, motivating the participation of citizens and of the government in the management of their activities; and to a greater extent, (c) the Work Integration Social Enterprises (WISE's), organizations that promote social inclusion and work (Comini et al. 2012).

Despite the main terms having only been disseminated in the last 30 years, empreender businesses in order to enable social inclusion and consequently improve well-being is a behavior that dates back to the end of the eighteenth century and can be seen as a cultural practice in accordance with the Behavior Analysis.

\section{Behavior Analysis and the Cultural Practice of the Social Enterprises}

Deriving the logic of the natural selection model by Charles Darwin to the behavior of organisms, Burrhus F. Skinner established the Behavior Analysis, a natural science that studies behavior based on the interaction between individuals and environment (Skinner 1981; Baum 1999). In order to do so, at the level of behavioral study of the individual a three-term contingency is adopted - or simply contingency, a descriptive and explanatory paradigm constituted by the environmental events that rise as a consequence of the behavior of an individual which determine the function of the anteceding context in which said behavior is inserted in. Going beyond the contributions of Ivan Pavlov, who favored the reflex behavior, in other words, that which, being innate or acquired by respondent learning, occurs in an involuntary manner as a response to environmental alterations, Skinner introduced the concept of operant behavior, actions that influence the environment and consequently transform the way in which the organism behaves (Glassman and Hadad 2006). Conscious of the potential impact of human behavior and that this is the result of specific conditions, Skinner (1981) suggests that it is possible to predict 
and control the actions of individuals, as well as to plan the cultural practices of a society. For this it is necessary not only to know the individual contingencies, but also to explore the process in which said contingencies that act upon an individual affect or are affected by the ones that are acting upon another individual. It is precisely that interlocking of individual contingencies what characterizes the cultural practices, a social phenomenon that came to have a new analysis unit based on the contributions of Sigrid S. Glenn, who proposed the study of the metacontingencies as an alternative to the contingencies to analyze cultural practices in light of the theoretical inheritance of Skinner.

Within the behaviorist context, cultural practices correspond to the "repetition of analogous operant behavior across individuals of a single generation and across generations of individuals" (Glenn 1991, p. 60). Glenn (1991) goes on to say that it is common that cultural practices contain an aggregate product, an additional element subsequent to the interlocking of contingencies that corresponds in fact to the result, the product of the behavior of different people. Thus, the metacontingency tends to function as an analysis unit that describes the relations among the interlocking cultural consequences and their aggregate product (Glenn and Malott 2004; Borlotti and D’Agostino 2007).

The purpose of this study is not to develop an in-depth analysis to describe the cultural-behavioral phenomenon of the social enterprises. However, it is possible to make a brief characterization of this phenomenon as a cultural practice in order to open a new angle by means of which the social enterprises may be observed and studied.

Taking the most traditional social enterprise as an example, the cooperative, it is possible to observe the components that characterize a cultural practice. One of the first documented cooperative enterprises in history was formed by the workers of the Woolwich and Chatham shipyard, in 1763 England. They founded a cereal mill and a bakery in order to escape the abusive prices that were monopolized by local millers (Cole 1991; Veiga and Fonseca 1999). In the composition of the contingencies involved, it is possible to observe that the benefit of acquiring flour and bread at more accessible prices (selecting consequence) led said workers to undertake their own mill and bakery (behavior) as an alternative to the restriction imposed by the high prices in that market (antecedent context).

Constituting cooperatives seemed to be a good alternative for the improvement of the living conditions of the working class in face of the hard reality of low salaries and terrible working conditions imposed by the bourgeoisie. The cooperative corresponded to an entrepreneurial organization composed by a working community that was the owner of the means of production, technology, and other resources as well as of the financial surpluses arising from the commercialization of the produced goods and services.

In what concerns the characterization of the cultural practice, the repetition of analogous operant behavior mentioned by Glenn (1991) may be noted from the pioneering experiences that promoted many groups of workers to have similar initiatives to those of the Woolwich and Chatham workers, constituting other cooperatives in the United Kingdom, France, and Germany between the end of the $18^{\text {th }}$ century and the mid-nineteenth century. Nonetheless, it was the projection of 
the Rochdale Society of Equitable Pioneers which definitely popularized the new organizational concept. The small textile company of the northeast England which began with 28 weavers later expanded its activities transforming local cooperative enterprises in affiliate enterprises. Said initiative yielded considerable gains in the hiring of goods and services and moved on to be reproduced by other cooperatives. Innovations in the distribution and in the retail, along with the advance in the industry and the urbanization created a favorable environment for cooperatives to multiply. By 1881 approximately one thousand cooperatives existed already, with close to 550 thousand associates. In 1900, only in Great Britain it was already possible to count close to 1.7 million members (Singer 2002). During the twentieth century, other important initiatives stood out and contributed for the cooperative movement to prosper. An example is the Mondragón Corporación Cooperativa, a Spanish group that brings more than 250 companies together, has international participation and is considered the biggest worker cooperative enterprise in the world. Currently, the international cooperative alliance (ICA) estimates that the cooperative movement groups close to one billion members and employs close to 250 million people around the world. One of his most studies revealed that only the 300 biggest cooperative companies moved 2.2 trillion dollars in businesses in 2012, equivalent to Brazil's GNP (Carini et al. 2014).

An aggregate product that can be easily highlighted as a generalized result of this advance of the cooperatives throughout generations and the improvement is the conditions of life of the workers. Said benefit directly affects the behavioral relations that produce it, causing feedback to be given to the cultural practice. Other aggregate products can be related to the increase in the market competitiveness, regulating of working conditions, rise of the professional associations, institution of the incentives by the Government, etc.

Generally speaking, the contemporary forms of social Enterprise expanded the scope of beneficiaries, previously reserved for their own members, in order to attend to different excluded groups or even an entire community. Said recent expansion is related with the triggering of contexts that restricted the well-being in several regions of the world starting from the 1980s such as the reduction in the financing of the public social programs, the bad functioning of the Government and the increase of unemployment (Defourny and Nyssens 2010; Kerlin 2010). During the 1990s, government initiatives, educational and research institution and the civil society, the cultural practice spreads as a concrete alternative for the dealing with social problems.

\section{Method}

The study started with the selection of articles published in international journals during August and September 2013, through the website of scientific journals of Fundação Coordenação de Aperfeiçoamento de Pessoal de Nível Superior (Capes), an entity related to the Brazilian Ministry of Education which provides to the Brazilian educational institutions indexed archive of 130 referential bases. The access to the website was performed by remote connection intermediated by Rede 
Nacional de Ensino e Pesquisa (RNP), through an user profile linked to Universidade Federal do Espírito Santo (Ufes).

In a general query in the available archives, search was made for peer-reviewed articles published in the last ten years in English with the full content available and with at least one of the following keywords: social enterprise, social business, or inclusive business associated to perspectives of social enterprise described by Comini et al. (2012). Conciliating search results, 39 articles were identified.

After general query, which imposes the Capes's search standard mechanism on all databases, an advanced search was conducted through the archives grouped in the website in specific areas and subcategories. In this other format, search rules obey to criteria of each searched database, ranging mainly in options of Boolean operators and truncation of terms in relation to the Capes's general query. The Social Sciences and Humanities area were chosen, among the subcategories: Public and Business Administration, Geography, Economics, Accounting, Sociology, Anthropology, Psychology, Political Science, and Education, respectively.

With the results, 72 articles were added to the initial selection, computing a total of 111 articles which were analyzed in this study (from 16 different referential bases).

The information of each article was classified in this study as follows:

1. Information on the article source: authors, nationality, department or area of research, publication year, journal name, and the database in which it was located;

2. Type of research: basic for studies that develop knowledge apart from its practical use; or applied for research with direct application of knowledge in solving problems (Cozby 2003);

3. Research Method: qualitative, quantitative or mixed, according to the features suggested by Creswell (2007);

4. Article type: empirical for studies based on surveys produced in experiments, survey of opinions, and/or systematic behavior observation; theoretical for reviews of the literature, methodological studies, and other distinct types;

5. Logic of the theoretical work: "verbal," if the ideas are expressed by a chain of textual arguments; or "numeral," if the ideas are expressed by mathematical equations (Ackerman et al. 1999);

6. Theoretical approach: classified in accordance to scientific subareas by mentions to the author or by the identification of the main theoretical references used;

7. Method of the empirical study: predominant category by which the data collection was conducted and served as the basis for the empirical study: behavior observation, experiment, or survey (Günther 2006);

In order to understand the research interests, the articles were grouped by categories of subject. These categories emerged from the following process: (1) development of syntheses of the goals and research problems associated with conclusions and results achieved in each article (called extended subject); (2) preparation of abstracts of the extended subjects in a small group of terms that was 
called restricted subject; (3) comparison of restricted subjects of each article and grouping by similarity, thus forming 10 categories that are explained below.

- Adaptability-works of authors such as Johanisova et al. (2013), which investigated the adaptation of social businesses to economic crisis scenarios or degrowth, as well as other studies related to the dualistic nature of social and economic aims; a relevant legislation or proposing of a more adequate legal structure and other adaptations;

- Entrepreneurship - articles that, despite having the keywords addressed in this study, only cite the subject and focus on the phenomenon of social entrepreneurship, as in Penedo and McLean (2006);

- Social exclusion-studies involving social business with focus on marginalized groups, such as children and youth at situation of risk, people with mental disorders, or as in the research of Wilson (2012), communities with financial vulnerability and low-income consumers;

- Management - works of author such as Lane and Casile (2011) who focused on the understanding or proposition of techniques and methods for improving business management. Some issues related to this category are management of organizational processes, strategies of resource allocation, management with indicators, and evaluation of the investment's social return;

- Social intermediation - for instance, article written by Nwankwo et al. (2007) who analyzed cases in which social businesses intermediate the relation between organizations interested in solving social problems and poor communities through plans of governmental initiatives, nonprofit entities, or related to corporate social responsibility;

- Regionalisms - studies that comprehend business peculiarities of a particular country or region, or that use comparative studies among different regions, such as the Park and Wilding (2013) who compared government policy in UK and South Korea;

- Profiles and skills — articles that reported features related to the profile of social entrepreneurs, construction and maintenance of organizational identity, satisfaction measurement, and work quality as well as specific skills observed in some enterprises analyzed. This category embraces, among others, Ryzin et al. (2009), who described the profile of the social entrepreneur in the United States;

- Nonprofit sector - comprehends studies related to changes in the third sector, as in the studies of Etxezarreta and Bakaikoa (2012), as well as the development of Social Economy and Social outsourcing as a political strategy of the State;

- Sustainability - analyses of social businesses applied in the management of municipal waste and for social solutions through recycling industries, as in the study of Sharpen (2006);

- Types and models - proposals for the characterization of distinct social business models; search for patterns that distinguish specific types of enterprise, and comparisons of scenarios that influenced regional identity and different concepts found throughout the world. Some efforts in this direction can be illustrated with the tri-value social enterprises of Herranz et al. (2011), the integrated enterprise 
of Schieffer and Lessem (2009) and the three perspectives of social business of Comini et al. (2012).

The identification of 10 categories is just a fraction of a diversity of subjects, since 13 articles presented no similarity between the formed groups and even among themselves, thus making a total of 23 different research interests about the topic social enterprise.

The data analysis and the results presentation followed premises of a certain type of study known as Bibliometrics (Buonocore 1952; Estivals 1970; Otlet 1934; Pritchard 1969). The bibliometric method is based on the formation of quantitative data from the application of statistics on the elements obtained from scientific publications, to measure what was written about a particular subject. This can be simply understood as the use of statistical or mathematical methods in a set of references (Rostaing 1996).

\section{Results}

As presented in Table 2, most part of the articles (54.1\%) was found in Emerald Management eJournals. The second referential basis with the largest volume of publications $(17.1 \%)$ was Springer Science \& Business Media BV. In third and fourth place comes John Wiley \& Sons, Inc. (8.1 \%) and Sage Publications (5.4 \%), respectively. Other bases represent less than $1 / 6$ of results $(15.3 \%)$.

Sixteen referential bases came from 42 scientific journals, which are listed in Table 3. In this table, it is possible to observe that Social Enterprise Journal is the periodic with more results, 55 articles published. The reason for this quantity of articles is because the journal is specialized in the subject. In contrast, most part of the journals listed $(81 \%)$ was selected by presenting only one paper within the search filters standards mentioned in the previous section.

The data in Table 3 also present the variability of the recognition of impact and quality of the journals used. Considering two measures of recognition, from the Journal Citation Reports and Capes, we found journals with impact ranging from none to 3799 (Journal of Management Studies) factor, and with scores in the qualifying system WebQualis oscillating between none and A1 (5 journals).

The evolution of scientific production related to the subject is presented in Illustration 1. The interval between 2004 and 2013 has an irregular curve of growth as illustrated by the continuous line of the graphic representation. The reason for the decrease of publications in the 2008-2010 period is easily explained. In those and in the following years, the journal with the highest volume of publications, Social Enterprise Journal, did not inserted as keywords the terms we searched in our study. However, considering the specificity of the journal, it seems that all the journal issues are directly related to the topic. Thus adjustment of the results to the journal mentioned makes a more realistic projection of the growth of publications in the period studied (which is presented as a dashed line in Illustration 1).

In the case of partnerships and co-authorships, 223 researchers were responsible for the scientific production related to subject presented in the previous paragraph. 


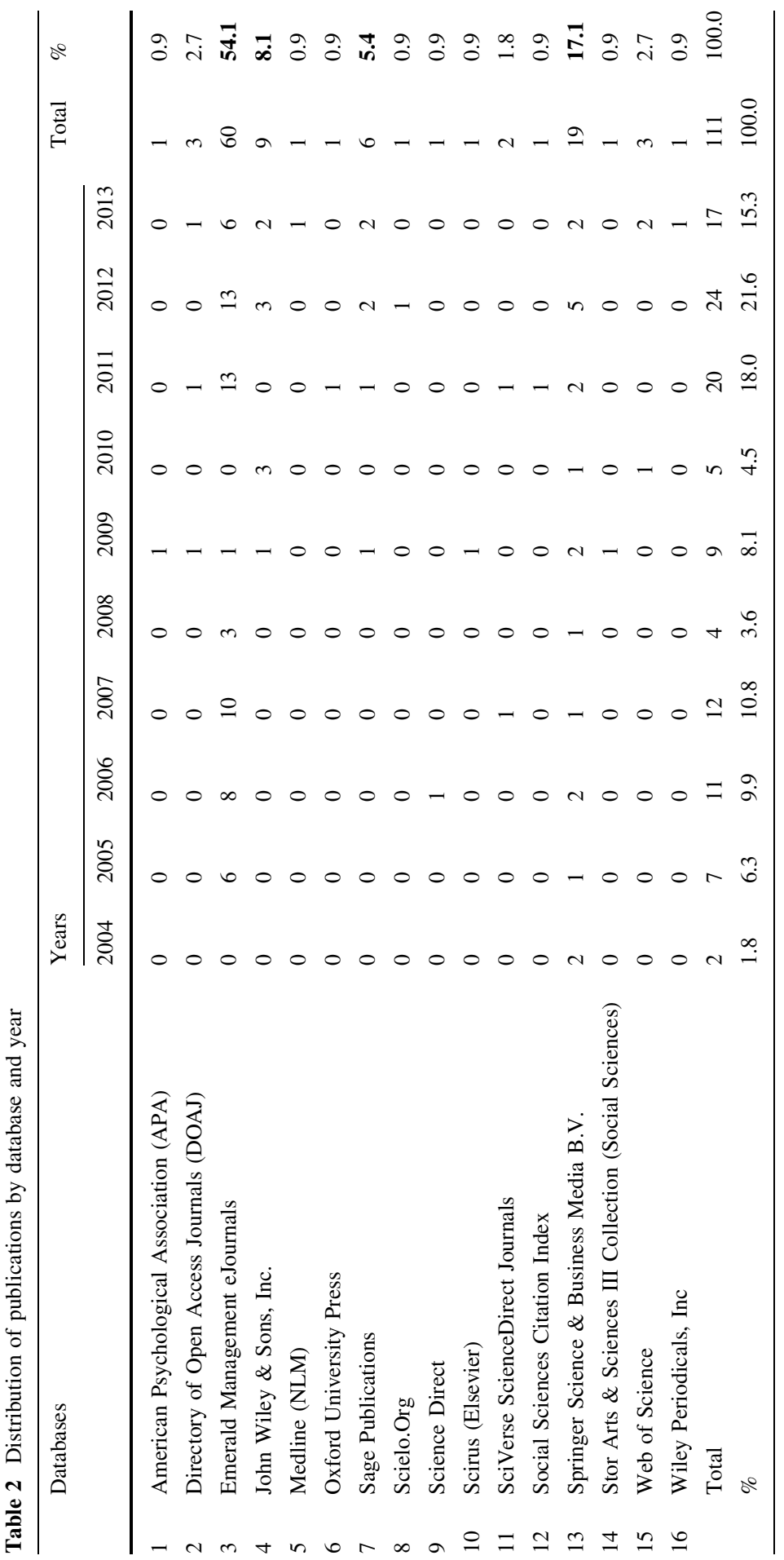


Table 3 Research production by periodic

\begin{tabular}{|c|c|c|c|c|}
\hline $\begin{array}{l}\text { No. of } \\
\text { articles }\end{array}$ & Periodic & Subject category & $\begin{array}{l}\text { Impact } \\
\text { factor }\end{array}$ & Webqualis \\
\hline 55 & Social Enterprise Journal & Business \& ethics & No & No \\
\hline 6 & $\begin{array}{l}\text { VOLUNTAS: International Journal of } \\
\text { Voluntary and Nonprofit Organizations }\end{array}$ & Social issues & 0.881 & A2 \\
\hline \multirow[t]{2}{*}{4} & Journal of Business Ethics & Business \& ethics & 1253 & B1 \\
\hline & Nonprofit and Voluntary Sector Quarterly & Social issues & 1490 & A1 \\
\hline \multirow[t]{4}{*}{2} & Annals of Public and Cooperative Economics & Business & No & A2 \\
\hline & Area & Geography & 1685 & No \\
\hline & $\begin{array}{l}\text { International Entrepreneurship and } \\
\text { Management Journal }\end{array}$ & Entrepreneurship & No & B3 \\
\hline & Journal of International Development & $\begin{array}{l}\text { Planning \& } \\
\text { development }\end{array}$ & 0.716 & B3 \\
\hline \multirow[t]{20}{*}{1} & $\begin{array}{l}\text { Australasian Accounting Business and } \\
\text { Finance }\end{array}$ & $\begin{array}{l}\text { Accounting; finance \& } \\
\text { banking research }\end{array}$ & No & No \\
\hline & Community Mental Health Journal & Psychiatric & No & A2 \\
\hline & $\begin{array}{l}\text { Human Factors and Ergonomics in } \\
\text { Manufacturing \& Service Industries }\end{array}$ & Ergonomics & 0.624 & B1 \\
\hline & Humanomics & Economics \& finance & No & B1 \\
\hline & iBusiness & $\begin{array}{l}\text { Information technology } \\
\text { industries }\end{array}$ & No & B3 \\
\hline & $\begin{array}{l}\text { International Journal of Entrepreneurial } \\
\text { Behavior \& Research }\end{array}$ & Entrepreneurship & No & No \\
\hline & International Journal of Social Welfare & Social work & 0.795 & No \\
\hline & $\begin{array}{l}\text { International Journal of Sustainability in } \\
\text { Higher Education }\end{array}$ & $\begin{array}{l}\text { Sustainable } \\
\text { development }\end{array}$ & 0.824 & $\mathrm{~A} 2$ \\
\hline & Journal of Cleaner Production & $\begin{array}{l}\text { Policies \& educational } \\
\text { programs }\end{array}$ & 3398 & $\mathrm{~A} 2$ \\
\hline & Journal of Consumer Policy & $\begin{array}{l}\text { Consumers in less } \\
\text { affluent societies }\end{array}$ & No & A2 \\
\hline & Journal of Economic Geography & $\begin{array}{l}\text { Geography \& } \\
\text { economics }\end{array}$ & 2600 & No \\
\hline & Journal of Economic Perspectives & Business \& economics & No & A1 \\
\hline & Journal of Environmental Protection & $\begin{array}{l}\text { Technology \& } \\
\text { environmental } \\
\text { science }\end{array}$ & No & B2 \\
\hline & Journal of Macromarketing & Business & 0.846 & No \\
\hline & Journal of Management Studies & Business & 3799 & B2 \\
\hline & Journal of public policies and territories & $\begin{array}{l}\text { Tourism, development, } \\
\text { and territory }\end{array}$ & No & No \\
\hline & Journal of Rural Studies & $\begin{array}{l}\text { Planning \& } \\
\text { development }\end{array}$ & 1786 & No \\
\hline & Journal of Social Entrepreneurship & Business & No & No \\
\hline & Journal of World Business & Business & 2617 & No \\
\hline & Organization Studies & Management & 2190 & A1 \\
\hline
\end{tabular}


Table 3 continued

\begin{tabular}{|c|c|c|c|c|}
\hline $\begin{array}{l}\text { No. of } \\
\text { articles }\end{array}$ & Periodic & Subject category & $\begin{array}{l}\text { Impact } \\
\text { factor }\end{array}$ & Webqualis \\
\hline & Psychiatric Rehabilitation Journal & $\begin{array}{l}\text { Psychiatric; } \\
\text { rehabilitation }\end{array}$ & 1159 & No \\
\hline & Public Organization Review & Public organization & No & No \\
\hline & Quality of Life Research & $\begin{array}{l}\text { Health; policy \& } \\
\text { services }\end{array}$ & 2412 & $\mathbf{A 1}$ \\
\hline & Revista de Administração (USP). & Business & No & A2 \\
\hline & Service Business & Business \& management & 0.571 & B2 \\
\hline & Small Business Economics & $\begin{array}{l}\text { Business; economics } \\
\text { \&management }\end{array}$ & 1130 & B3 \\
\hline & Social Policy \& Administration & $\begin{array}{l}\text { Planning \& } \\
\text { development }\end{array}$ & 0.976 & No \\
\hline & Social Responsability Journal & Business; ethics \& law & No & No \\
\hline & Society and Business Review & Business; ethics \& law & No & No \\
\hline & Socio-Economic Planning Sciences & Business \& ethics & No & A1 \\
\hline & Systems Research and Behavioral Science & $\begin{array}{l}\text { Management \& social } \\
\text { sciences }\end{array}$ & 0.474 & A2 \\
\hline & $\begin{array}{l}\text { The Australasian Journal of Disaster and } \\
\text { Trauma Studies }\end{array}$ & Disaster \& trauma studies & No & No \\
\hline & Transition Studies Review & Strategic studies & No & No \\
\hline & Waste Management & Solid waste management & 2485 & A2 \\
\hline
\end{tabular}

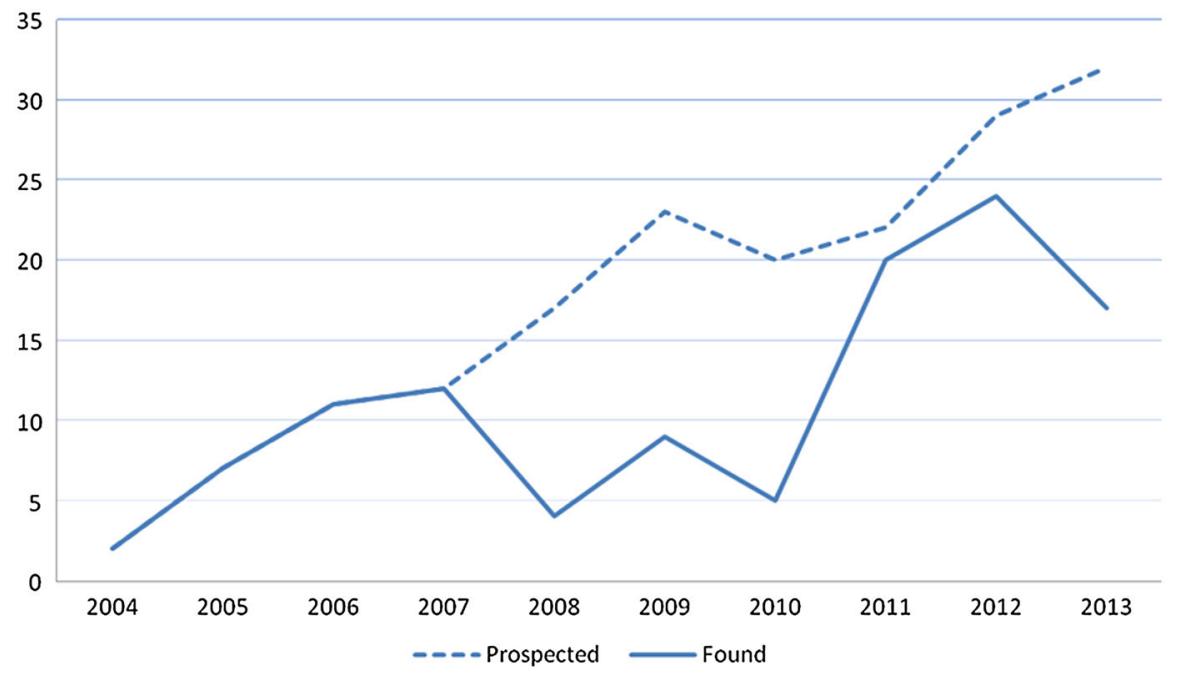

Illustration 1 Evolution of scientific production 
Table 4 Research production by individual authors and affiliation

\begin{tabular}{llll}
\hline $\begin{array}{l}\text { No. of } \\
\text { articles }\end{array}$ & Authors & Affiliation & Country \\
\hline 4 & Helen Haugh & University of Cambridge & \\
& Paul Tracey & University of Warwick & UK \\
3 & Jacques Defourny & University of Liege & UK \\
& Benjamin Huybrechts & University of Liege & Belgium \\
& Janelle A. Kerlin & Georgia State University & Belgium \\
& Eric Bidet & Le Mans University & USA \\
& Mike Bull & Manchester Metropolitan University Business & France \\
& Kate Cooney & Yale University School of Management & UK \\
& Nelarine Cornelius & Brunel University & USA \\
& Shaheena Janjuha- & Brunel University & UK \\
& Jivraj & Middlesex University Business School & UK \\
& Fergus Lyon & Catholic University of Louvain & UK \\
& Marthe Nyssens & University of London & Belgium \\
& Mathew Todres & Brunel University & UK \\
& Adrian Woods & Various & UK \\
& 189 authors & & Various \\
\hline
\end{tabular}

Of these, some stand out with a greater number of publications. Table 4 identifies an author with more than 2 articles, his/her educational institution and nationality. At the first place are the British authors Helen Haugh (University of Cambridge) and Paul Tracey (University of Warwick), each one with four published articles. Then the Belgians Jacques Defourny and Benjamin Huybrechts (University of Liege), and the North American Janelle A. Kerlin (Georgia State University), with three papers each. The majority of researchers $(84.8 \%)$ are responsible for only one article.

Illustration 2 was developed according to author's nationality. Two regions stand out in relation of the subject studied in the last 10 years. The UK has the large amount of research in the area, being the European State with the major contribution for the studies. It represents $42 \%$ of the world's scientific literature on the subject. North America also concentrates a large part of the scientific production in the area-USA is responsible for $13 \%$ of the research on the topic. The sum of researches from Asia computes $9 \%$, while $7 \%$ are distributed separately in Latin America (Brazil), Africa (Nigeria), and Oceania (Australia and New Zealand).

As it is observed in Table 5, the most representative category of the subject is the Management (18\%), followed by Regionalisms (14.4\%) and Social Exclusion $(12.6 \%)$. Nevertheless, the authors of the business area (Management, Accounting, Economics), which were the main contributors to the scientific production $(59.5 \%)$, not only focused on Management, but on almost all categories. 


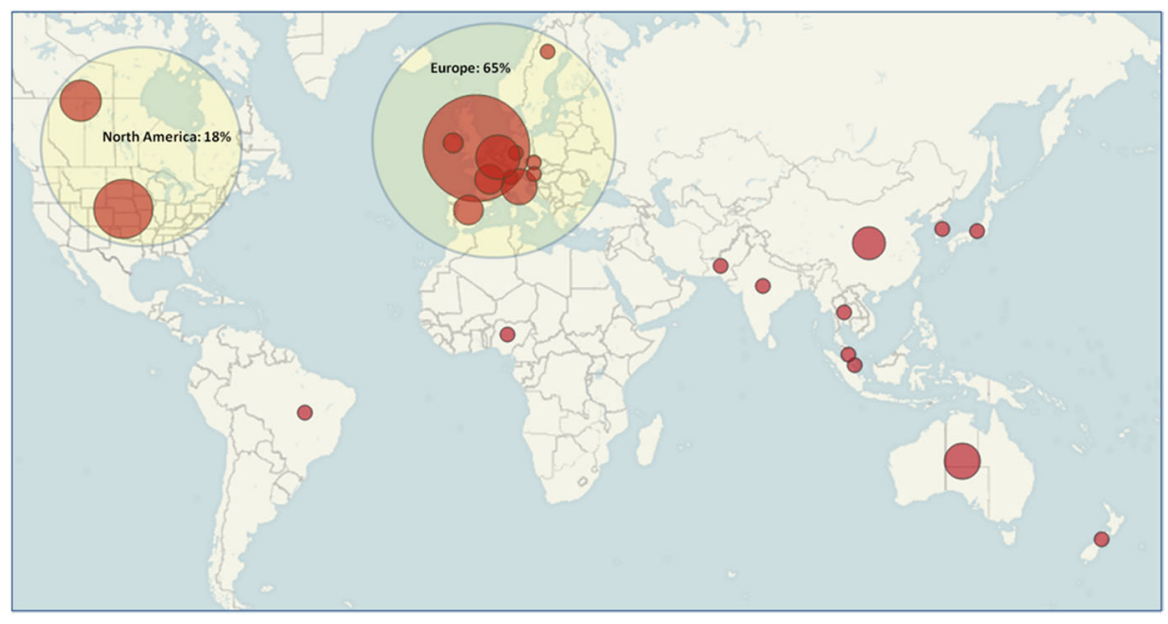

Illustration 2 Concentration of researches in the world

Even with a significant percentage of research areas not mentioned in the articles $(13.5 \%)$, it is still possible to verify in Table 5 that there was a significant variety of areas of interest in social business.

As more than half of the authors are linked to research areas related to business, the predominant theoretical approach $(60.4 \%)$ is Managerial, although we can identify another 10 theoretical perspectives adopted in studies, but with little representation compared to the whole, as the observed in Table $6.73 .9 \%$ of researches are basic, and $26.2 \%$ of the studies were classified as applied. For the method, there is no equality in the distribution. The qualitative research predominates $(90.1 \%)$; the quantitative method and the use of mixed methods represent 1.8 and $8.1 \%$, respectively.

As illustrated in Table 7, the articles were also classified as theoretical or empirical. The theoretical studies were the majority $(62.2 \%)$ with the typically verbal argumentation. Although no study was only based on mathematical logic, two theoretical articles associated it to the verbal construction of their argumentation. Empirical studies represent $37.8 \%$ of the studies and the predominant method was survey (36\%). However, of the 42 empirical articles that collected data through survey, in which structured and semi-structured interviews prevailed, nine articles also used observations and two used focus on group. But no empirical study collected data only through observations.

Following the tradition of the Managerial Perspective, 11 empirical articles used business cases to illustrate various propositions. 10 other empirical papers explicitly presented the techniques of data analysis used, as well as the software used for the qualitative analysis, which were (a) content analysis (one article); (b) discourse analysis (three articles); (c) factor analysis (one article); (d) use of performance scores (one article); (e) use of descriptive statistics (two articles); (f) use of software for quantitative analysis, respectively Nvivo and Atlas.ti (two articles); 


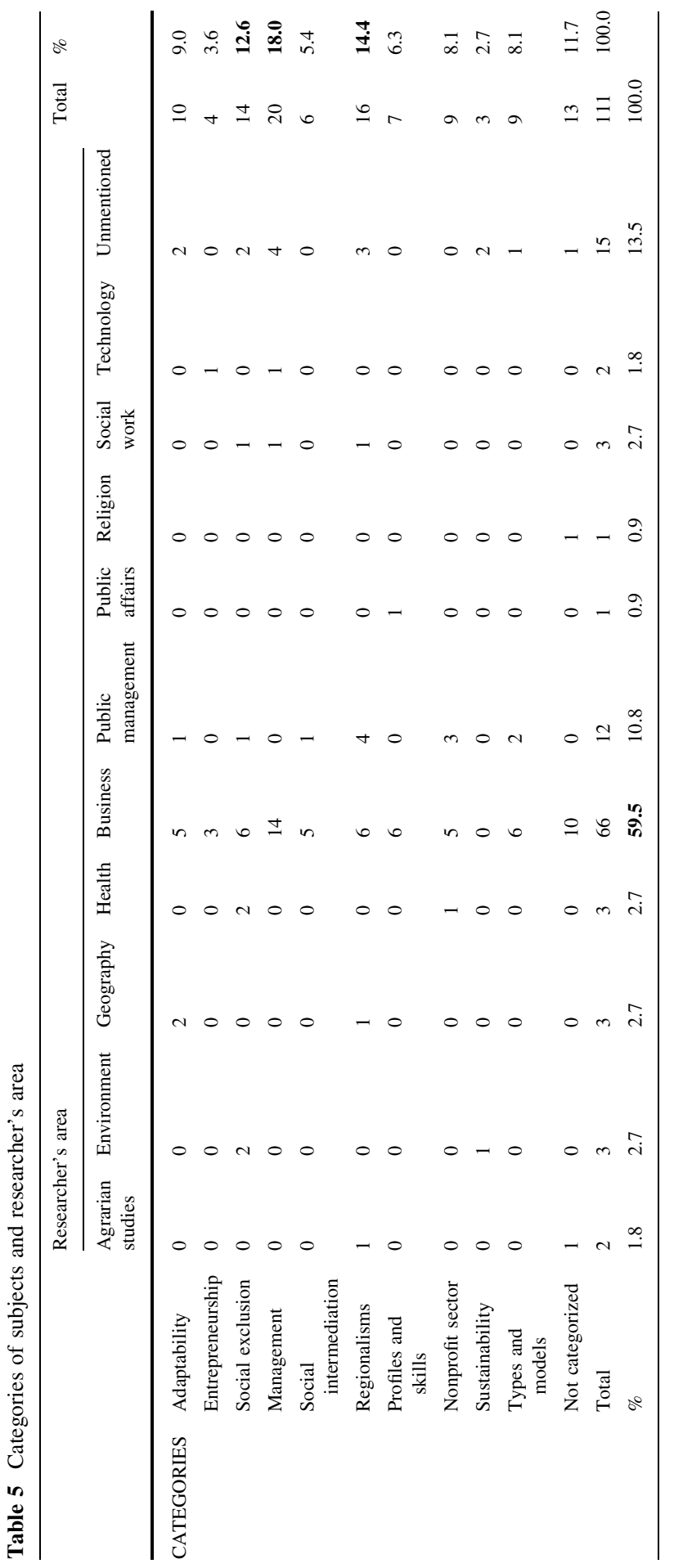


Table 6 Methodological classification of studies

\begin{tabular}{|c|c|c|c|c|c|c|}
\hline \multirow[t]{3}{*}{ Theoretical approach } & \multicolumn{6}{|c|}{ Research } \\
\hline & \multicolumn{2}{|l|}{ Kinds } & \multirow[t]{2}{*}{ Total $(\%)$} & \multicolumn{3}{|l|}{ Methods } \\
\hline & Basic & Applied & & Quality & Quantity & Mixed \\
\hline Administrative & 8 & 0 & 7.2 & 7 & 0 & 1 \\
\hline Anthropological & 0 & 1 & 0.9 & 1 & 0 & 0 \\
\hline Economic & 5 & 1 & 5.4 & 6 & 0 & 0 \\
\hline Environmental & 1 & 0 & 0.9 & 1 & 0 & 0 \\
\hline Geographical & 2 & 0 & 1.8 & 2 & 0 & 0 \\
\hline Managerial & 49 & 18 & 60.4 & 61 & 2 & 4 \\
\hline Philosophical & 0 & 1 & 0.9 & 1 & 0 & 0 \\
\hline Psychiatric & 0 & 3 & 2.7 & 2 & 0 & 1 \\
\hline Psychological & 1 & 0 & 0.9 & 1 & 0 & 0 \\
\hline Sociological & 2 & 1 & 2.7 & 3 & 0 & 0 \\
\hline Statistical & 1 & 0 & 0.9 & 0 & 0 & 1 \\
\hline Unidentified & 13 & 4 & 15.3 & 15 & 0 & 2 \\
\hline Total & 82 & 29 & 100.0 & 100 & 2 & 9 \\
\hline$\%$ & 73.9 & 26.1 & & 90.1 & 1.8 & 8.1 \\
\hline
\end{tabular}

\section{Conclusions}

Stimulated by a strong and massive militancy, government policies, privileged space in the media system and a noble cause, the movement of social enterprise, as the mobilization of this peculiar type of business has been empirically called, has reached global dimensions as an alternative solution to major social problems such as poverty and unemployment, and has stimulated a kind of social entrepreneurship with local actions especially focused on excluded communities. It is a proposal that is not against capitalism and uses its free market mechanisms to fill the space left by Governments and programs of sustainability and corporate social responsibility. Given the global scale of the phenomenon, this article had the purpose of finding out whether the research on social enterprises as a cultural practice is something that is under explored. In order to do so, it was made a bibliometric analysis of the scientific literature on the different perspectives attributed to the social enterprises. The research did not identify any study addressing, even in an underlying manner, the cultural dimension of this phenomenon.

The small number of publications found in the survey for the study confirms the statement that "despite the emerging practice of social business, and its media attention, the phenomenon has been understudied in the academic literature" (Wilson and Post 2013, p. 716). However, the results present a growing tendency of this kind of study, confirming the supposed increase of the academic interest on the subject (Haugh 2012).

Applying a simple linear regression on the estimated production curve of Illustration 1, one can make projections-with $95.4 \%$ of confidence (Pearson's 
Table 7 Classification by types of papers

\begin{tabular}{lllll}
\hline Types of articles & Frequency & & $\%$ & 62.2 \\
\hline Theoretical & & 69 & 62.2 & \\
$\quad$ Verbal logic & 69 & & 0 & 37.8 \\
Mathematical logic & 0 & 42 & & \\
Empirical & 2 & & 1.8 & \\
Experiment & 40 & & 0 & 100 \\
Survey & 0 & 111 & & \\
Observation & & & & \\
Total & &
\end{tabular}

coefficient)—of a mean annual increment of $7.5 \%$ until 2020. Not bad for a research area relatively new. In fact a natural increase of the scientific production is expected to occur, as it is stimulated by the necessity of solutions and understandings of the phenomenon. This occurs because the global expansion of social enterprises is not only guided the local application of renowned models such as the North American and the British, but by the very expansion of markets in which these businesses already established act-as one can observe in the case of internationalization of British enterprises.

Another stimulating aspect for the evolution of the scientific production on social enterprises is the diverse nature of the journals that accept publications related to the topic. There are over 25 different niches in which the journals studied focus on Management, Geography, Ethics, Ergonomics, Psychiatry, Accounting, Technology, Sustainability, Public Policy, Tourism, Law etc. Such acceptance indicates that there is room in the scientific community for the publication of studies on social enterprises based on several perspectives, what reinforces the actuation of potential researchers in exploration of subject in different areas of knowledge. With diversity relevance is not lost, since the majority of the journals cited are known for their quality and impact.

Despite the variety of areas of interest in social enterprises, the classification of articles by categories of subject allowed us to note that most part of researches have concentrated their studies on issues concerning to the management of enterprises. The second most popular interest found in the search referred to comparisons of regional characteristics, a tendency already observed by Kerlin (2010). Despite the significant volume of authors in the business area and the interest in understanding or solving specific problems of management, the applied research is curiously incipient, representing $1 / 4$ of all the production analyzed.

Furthermore, information about the techniques used for the collection and analysis of data could not be classified due to the innocuous representativity of the empirical articles that mentioned them. These observations indicate a higher dedication to the theoretical structuring of the area, a search for an adaptation of common principles, and methods to Managerilism for the reality of this new organizational environment. Nonetheless, as Curtis (2008) stated, the theoretical perspective of Managerilism provides a good explanatory framework that contributes to the understanding of social 
enterprises, but it is also necessary to expand the theoretical framework by exploring other approaches. Different theoretical perspectives can emerge from a significant participation of other areas of knowledge, something that can contribute to the diversification of the scientific methods used, and to the reduction of the usual theoretical fragility found in the majority of case studies and in other approaches that have been performed in the business area.

Finally, it is possible to conclude that the field of research in social enterprises is developing with the initiative of a few pioneers who faced the challenge of exploring an unknown but fascinating environment, with the potential of establishing a new perspective of development and socio-economic equality. Difficulties and mistakes are typical of pioneering explorations. One should learn with experience and search for improvements in performance and results. The increased rigidity of the methods used and the increased diversity of perspectives on the phenomenon tend to produce a qualitative evolution of the scientific collaboration for the expansion of social enterprises and the benefits created by them. Among the perspectives that allow a holistic understanding of the area, we suggest the use approaches linked to the Behavioral Analysis of Culture in order to broaden the understanding of this global phenomenon, and to facilitate the application of models and solutions already tested or in development. The contemporary Behaviorism in particular, accustomed the social matters in an important manner-but primarily theoretical in Skinner-is invigorating the field of the analysis of cultural facts. Numerous studies have been published since the 1980s, all evidencing the feasibility of the planning of the contingencies for the most varied topics: pollution control, conservation and preservation of water resources, study of antecedents and consequences in legislation, urban mobility, solidary economy through cooperation, dengue control, and many other sectors. The planned reorganization of the possible interlockings among the behavior of two or more people seems to evidence the Psychology — and in a more specific manner the Behavior Analysis - as an important source of strategies for a behavioral planning in the field of social enterprises focusing on group actions that articulately seek social justice.

For the future bibliometric studies about the subject, it is recommended the database expansion with the adoption of publications in languages other than English. Neo-latin and eastern languages can contribute with studies of realities that are not so known to the Western world, in addition to better represent the reality of authors from developing countries unfamiliar with the English language.

Acknowledgments The author would like to thank Instituto Federal de Educação, Ciência e Tecnologia do Espírito Santo for funding translation service.

\section{References}

Ackerman, D. S., Chandy, R. K., \& Tellis, G. J. (1999). In search of diversity: the record of major marketing journals. Journal of Marketing Research, 36(2), 120-131.

Alter, S. K. (2002). Case studies in social enterprise: Counterpart international's experience. Washington, DC: Counterpart International.

Baum, W. M. (1999). Compreender o behaviorismo: Ciência, comportamento e cultura. Porto Alegre: Editora Artes Médicas Sul. 
Bidet, E., \& Eum, H. S. (2011). Social enterprise in South Korea: history and iversity. Social Enterprise Journal, 7(1), 69-85.

Borlotti, R., \& D’Agostino, R. G. (2007). Ações pelo controle reprodutivo e posse responsável de animais domésticos interpretadas à luz do conceito de metacontingência. Revista Brasileira de Análise do Comportamento, 3, 17-28.

Buonocore, J. D. (1952). Vocabulário bibliográfico: términos relativos al libro, aldocumento, a la biblioteca y a la imprenta, para uso de escritores, bibliógrafos, bibliófilos, bibliotecários, archivistas, libreros, editores encuadernadores y tipógrafos. Santa Fé: Libreria y Editorial Castellvi.

Carini, C., Costa, E., Fontanari, E., Gotz, I., Ranicki, C. \& Rigotti, A. (2014), World Co-operative Monitor. Exploring the Co-operative Economy. Explorative Report 2014. ICA \& Euricse. Retrieved from http://monitor.coop/.

Cole, G. D. H. (1991). As primeiras cooperativas antes de Rochdale Democracia participação e autonomia cooperativa (pp. 30-41). São Leopoldo: Unisimos.

Comini, G., Barki, E., \& Aguiar, L. T. (2012). A three-pronged approach to social business: A Brazilian multi-case analysis. Revista de Administração (São Paulo), 47(3), 385-397. doi:10.1590/S008021072012000300004.

Cozby, P. C. (2003). Métodos de pesquisa em ciências do comportamento. São Paulo: Atlas.

Creswell, J. W. (2007). Projeto de pesquisa: métodos qualitativo, quantitativo e misto (L. d. O. d. Rocha, Trans. $2^{\mathrm{a}}$ ed.). Porto Alegre: Artmed.

Curtis, T. (2008). Finding that grit makes a pearl: A critical re-reading of research into social enterprise. International Journal of Entrepreneurial Behaviour \& Research, doi:10.1108/ 13552550810897650.

Dees, J. G. (2007). Taking social entrepreneurship seriously. Society, 44(3), 24-31. doi:10.1007/ BF02819936.

Defourny, J., \& Kim, S. Y. (2011). Emerging models of social enterprise in Eastern Asia: A cross-country analysis. Social Enterprise Journal, 7(1), 86-111. doi:10.1108/17508611111130176.

Defourny, J., \& Nyssens, M. (2008). Social enterprise in Europe: recent trends and developments. Social Enterprise Journal, 4(3), 202-228. doi:10.1108/17508610810922703.

Defourny, J., \& Nyssens, M. (2010). Conceptions of social enterprise and social entrepreneurship in Europe and the United States: Convergences and divergences. Journal of Social Entrepreneurship, 1(1), 32-53. doi:10.1080/19420670903442053.

Desa, G. (2007). Social entrepreneurship: Snapshots of a research field in emergence. Paper presented at the 3rd International Social Entrepreneurship Research Conference, Centre for Corporate Values and Responsibility (CVR), Frederiksberg, 18-19 June.

Diamond, J. M. (2001). Armas, germes e aço: os destinos das sociedades humanas (S. S. Costa, C. Cortes, P. Soares, Trads.). Rio de Janeiro: Record.

Diamond, J. M. (2005). Colapso: como as sociedades escolhem o fracasso ou o sucesso (A. Raposo, Trad.). Rio de Janeiro: Record.

Estivals, R. (1970). La estatistique bibliographique. Bulletin des Bibliotheques de France, 14(12), 481-502.

Etxezarreta, E., \& Bakaikoa, B. (2012). Changes in the welfare state and their impact on the social economy: contributions to the theoretical debate from a systemic and comparative approach. Annals of Public and Cooperative Economics, 83(3), 259-280.

Glassman, W. E., \& Hadad, M. (2006). Psicologia: Abordagens Atuais (4 ${ }^{\mathrm{a}}$ ed.). Porto Alegre: Artmed.

Glenn, S. S. (1988). Contingencies and metacontingencies: Toward a synthesis of behavior analysis and cultural materialism. The Behavior Analyst, 11, 161-179.

Glenn, S. S. (1991). Contingencies and metacontingencies: Relations among behavioral, cultural, and biological evolution. In P. A. Lamal (Ed.), Behavioral analysis of societies and cultural practices (pp. 39-73). New York: Hemisphere Publishing Corporation.

Glenn, S. S. (2003). Operant contingencies and the origin of cultures. In K. A. Lattal \& P. N. Chase (Eds.), Behavior theory and philosophy (pp. 223-242). New York: Klewer Academic/Plenum.

Glenn, S. S. (2004). Individual behavior, culture, and social change. The Behavior Analyst, 27, $133-151$.

Glenn, S. S., \& Malott, M. (2004). Complexity and selection: Implications for organizational change. Behavior and Social Issues, 13, 89-106.

Granados, M. L., Hlupic, V., Coakes, E., \& Mohamed, S. (2011). Social enterprise and social entrepreneurship research and theory: A bibliometric analysis from 1991 to 2010. Social Enterprise Journal, 7(3), 198-218. doi:10.1108/17508611111182368. 
Günther, H. (2006). Pesquisa qualitativa versus pesquisa quantitativa: Esta é a questão? Psicologia: Teoria e Pesquisa, 22(2), 201-210.

Hardin, G. (1968). The tragedy of the commons. Science, 162(3859), 1243-1248. doi:10.1126/science. 162.3859.1243.

Harris, M. (1979). Cultural materialism: The struggle for a science of culture. New York: Vintage.

Harris, M. (1980). Culture, people, nature: An introduction to general anthropology (3rd ed.). New York: Harper \& Row.

Harris, M. (2007). Cultural materialism and behavior analysis: Common problems and radical solutions. The Behavior Analyst, 30, 37-47.

Haugh, H. (2012). The importance of theory in social enterprise research. Social Enterprise Journal, 8(1), 7-15. doi:10.1108/17508611211226557.

Herranz, J, Jr, Council, L. R., \& McKay, B. (2011). Tri-value organization as a form of social enterprise. Nonprofit and Voluntary Sector Quarterly, 40(5), 829-849. doi:10.1177/0899764010369178.

Hill, T. L., Kothari, T. H., \& Shea, M. (2010). Patterns of meaning in the social entrepreneurship literature: a research platform. Journal of Social Entrepreneurship, 1(1), 5-31. doi:10.1080/ 19420670903442079.

Hoogendoorn, B., Pennings, E., \& Thurik, R. (2010). What do we know about social entrepreneurship: An analysis of empirical research. International Review of Entrepreneurship, 8(2), 1-42.

Johanisova, N., Crabtree, T., \& Fraňková, E. (2013). Social enterprises and non-market capitals: A path to degrowth? Journal of Cleaner Production, 38, 7-16. doi:10.1016/j.jclepro.2012.01.004.

Kerlin, J. A. (2006). Social enterprise in the United States and Europe understanding and learning from the differences. Voluntas International Journal of Voluntary and Nonprofit Organizations, 17(3), 246-262. doi:10.1007/s11266-006-9016-2.

Kerlin, J. A. (2010). A comparative analysis of the global emergence of social enterprise. VOLUNTAS: International Journal of Voluntary and Nonprofit Organizations, 21(2), 162-179. doi:10.1007/ s11266-010-9126-8.

Lane, M. D., \& Casile, M. (2011). Angels on the head of a pin: the SAC framework for performance measurement in social entrepreneurship ventures. Social Enterprise Journal, 7(3), 238-258. doi:10. $1108 / 17508611111182395$.

Malott, M., \& Glenn, S. S. (2006). Targets of intervention in cultural and behavioral change. Behavior and Social Issues, 15, 31-56.

Nwankwo, E., Phillips, N., \& Tracey, P. (2007). Social investment through community enterprise: The case of multinational corporations involvement in the development of Nigerian water resources. Journal of Business Ethics, 73(1), 91-101. doi:10.1007/s10551-006-9200-8.

O’Donohoe, N., Leijonhufvud, C., Saltuk, Y., Bugg-Levine, A., \& Brandenburg, M. (2010). Impact investments: An emerging asset class. Retrieved from http://www.rockefellerfoundation.org/blog/ impact-investments-emerging-asset.

Ostrom, E. (1990). Governing the commons: The evolution of institutions for collective action. New York City: Cambridge University Press.

Ostrom, E., Burger, J., Field, C. B., Norgaard, R. B., \& Policansky, D. (1999). Revisiting the commons: Local lessons, global challenges. Science, 284(5412), 278-282. doi:10.1126/science.284.5412.278.

Otlet, P. (1934). Traite de documentation: le livre sur le livre, theeorie et pratique. Bruxelles: Editiones Mundaneum.

Park, C., \& Wilding, M. (2013). Social enterprise policy design: Constructing social enterprise in the UK and Korea. International Journal of Social Welfare, 22(3), 236-247. doi:10.1111/j.1468-2397.2012. 00900.x.

Penedo, A. M., \& McLean, M. (2006). Social entrepreneurship: A critical review of the concept. Journal of World Business, 41(1), 56-65. doi:10.1016/j.jwb.2005.10.007.

Pritchard, A. (1969). Statistical bibliography or bibliometrics? Journal of Documentation, 25(4), 348-349.

Rostaing, H. (1996). La bibliométrie et ses techniques. Tolouse: Sciences de la Société.

Ryzin, G. G. V., Grossman, s, DiPadova-Stocks, L., \& Bergrud, E. (2009). Portrait of the social entrepreneur: Statistical evidence from a US Panel. VOLUNTAS: International Journal of Voluntary and Nonprofit Organizations, 20(2), 129-140. doi:10.1007/s11266-009-9081-4.

Saltuk, Y., El Idrissi, A., Bouri, A., Mudaliar, A., \& Schiff, H. (2014). Spotlight on the market: The impact investor survey. Retrieved from http://www.thegiin.org/cgi-bin/iowa/resources/research/594. html. 
Sampaio, A. A. S., \& Andery, M. A. P. A. (2010). Comportamento Social, Produção Agregada e Prática Cultural: Uma Análise Comportamental de Fenômenos Sociais. Psicologia: Teoria e Pesquisa, 26(1), 183-192.

Santos, B. S. (2005). Produzir para viver: os caminhos da produção não capitalista (2a ed., Vol. 2). Rio de Janeiro: Civilização Brasileira.

Schieffer, A., \& Lessem, R. (2009). Beyond social and private enterprise: Towards the integrated enterprise. Transition Studies Review, 15(4), 713-725. doi:10.1007/s11300-008-0040-3.

Sharpen, C. (2006). Social enterprise under the microscope: Comparing and contrasting Green-Works and ReBoot. Social Enterprise Journal, 2(1), 101-113. doi:10.1108/17508610680000716.

Short, J. C., Moss, T. W., \& Lumpkin, G. T. (2009). Research in social entrepreneurship: Past contributions and future opportunities. Strategic Entrepreneurship Journal, 3(2), 161-194. doi:10. 1002/sej.69.

Singer, P. (2002). Introdução à economia solidária ( $1^{\mathrm{a}}$ ed.). São Paulo: Editora Fundação Perseu Abramo.

Skinner, B. F. (1971). Beyond freedom and dignity. New York: Alfred A. Knopf.

Skinner, B. F. (1981). Selection by consequences. Science, 213(4507), 501-504. doi:10.1126/science. 7244649.

U.K. Cabinet Office (2013). Social enterprise: Market trends (Based upon the 2012 Small Business Survey). Retrieved from https://www.gov.uk/government/publications/social-enterprise-markettrends.

Veiga, S. M., \& Fonseca, I. (1999). Cooperativismo: uma revolução pacífica em ação. Rio de Janeiro: FASE.

Wilson, F., \& Post, J. E. (2013). Business models for people, planet (\& profits): Exploring the phenomena of social business, a market-based approach to social value creation. Small Business Economics, 40(3), 715-737. doi:10.1007/s11187-011-9401-0.

Wilson, T. A. (2012). Supporting social enterprises to support vulnerable. Journal of Consumer Policy, 35(2), 197-213. doi:10.1007/s10603-011-9182-5.

Yunus, M., \& Jolis, A. (2007). Banker to the poor: Micro-lending and the battle against world poverty $\left(3^{\mathrm{a}}\right.$ ed.). New York City: PublicAffairs. 